Journal of Teacher Education for Sustainability, vol. 11, no. 2, pp. 64-76, 2009

\title{
TO TRAIN OR NOT TO TRAIN?
}

\author{
Nwachukwu Prince Ololube, Samuel Amaele \\ University of Education, Port Harcourt, Nigeria \\ and Peter James Kpolovie \\ University of Port Harcourt, Nigeria
}

\begin{abstract}
This research paper examines the professional and non-professional methodological competencies of secondary school teachers in Nigeria. The main focus of this study is to probe the impact of professional and non-professional methodological competencies as a predictor of teaching effectiveness. Although this exploration is survey research, a questionnaire was used for data gathering, and multiple statistical procedures were employed in the analysis. This study contributes to the field both in terms of theory and practice. Theoretically, it provides an outline of school effectiveness and quality improvement that can be used as a basis for further research. The study identifies factors that create barriers to methodological competencies for the two categories of teachers used in this study. It also describes the present situation on the ground in Nigerian secondary schools. At the practical level, this outline might guide school leaders, education planners and policy makers in their school effectiveness and quality improvement endeavors.
\end{abstract}

Key words: professional; non-professional; teachers; classroom; methodological competencies.

\section{Introduction}

There are several methods of teaching that enable one to inculcate and provide students with insight during the instructional process (Harris \& Muijs, 2005; Ololube, 2005b). Dictionaries variously define insight using concepts such as 'the act of grasping the inward' or 'hidden nature of things', and 'the ability to perceive clearly or deeply into a phenomenon.' According to one online teacher web page, if insightfulness equals intelligence then we must look more closely at how we teach and ask questions. From the contemporary act of sketching a scene to the more traditional act of recitation, do our teaching methods engage the parts of students' minds from which insight springs (The New Curriculum, 2003)? These are questions this study tends to examine, vis-à-vis evaluating the common methods of teaching that help to provide students with insights.

There are also different levels of classroom competencies that teachers should possess in order to create quality in instruction (Creemers, 1994c). For example, teachers are expected not only to impart knowledge but also to foster the adjustment of students; 
understand student's basic cognitive and social problems; match curricular offering to levels of mental development; translate curricular specifications into relevant teaching materials; and provide smooth transitions from home to school and from one level of education to another. The traditional image of teachers as people who stand in front of the classroom and teach children has, for some years, been outdated. Teaching in modern society involves assisting students as they make worthwhile and satisfying adjustments to school work, to social groups, and to their occupations. If issues around these adjustments are not resolved, the individual child may not be able to fully appreciate his or her learning. As the principle duty of teachers remains to get the individual student to learn, it is also their duty to remove obstacles to learning. If proper adjustments are not made, friction and frustration will set in and successful learning will not take place (Stones, 1966). According to McDaniel, the essence of harmony, a lack of friction, a smooth give-and-take, and an interaction that is satisfying to cooperating parts of a social relationship, in other words, the reduction of frustration is central to making teaching and learning meaningful for the child and fostering in the child a prolonged interest in school (McDaniel in Amalaha, 1979). Thus it is expected that all classroom teachers should endeavor to discover what constitutes appropriate experiences for their students through professional teacher education and studies (Austin et al., 2003).

\section{Rationale for the study}

Getting education right has been a priority for most countries for some years, hence the current global trend in education reform. The present course of events and priorities in the education sector in Nigeria suggests that Nigeria is on the wrong side of getting our children's education right. In the past two decades, Nigeria has undergone a number of structural reforms in its educational system. However, it is frequently overlooked that most of the reforms do not focus on practices and policies designed to create school effectiveness and quality improvement vis-à-vis ensuring that policies are implemented as stipulated. At this juncture, Nigeria cannot afford to be on the wrong side of educational reforms if we are to be recognized by the international community of nations.

Secondary schools in Nigeria operate under the guidelines provided by the National Policy on Education (NPE) instituted in 1981 and revised in 1989 (Federal Government of Nigeria, 1989). This policy outlines the objectives of secondary schools, the caliber and qualifications of teachers that should be teaching in them, as well as the curriculum content and methodology to be employed. It is alarming, however, to note that in spite of the provisions of the National Policy on Education, there remain serious problems that hinder the further development of secondary school education in Nigeria. These problems include, but are not limited to, an acute shortage of professionally qualified teachers and the recruitment of unqualified and untrained individuals into teaching.

There are essentially two categories of teachers that are employed in Nigeria, those that are academically qualified and those that are professionally qualified to carry out instruction in the classroom. By academically qualified (non-professional) teachers, we mean teachers who have academic training without professional teacher training as a result of enrolment in an institution of higher learning where they obtained qualifications enabling them to secure lucrative employment. Professionally qualified teachers are teachers who acquire professional teacher training that provides them with professional knowledge, skills, techniques, and aptitude as different from a general education. This 
study has sought to measure these two categories of teachers found in Nigerian secondary schools to determine their methodological competencies and teaching skills and their effect on student academic achievement.

The primary aim of this study is to learn from other research on teachers' methodological competencies and apply the lessons of this research to policies intended to improve and fortify the deteriorating secondary educational system in Nigeria. In other words, the aim of this research is to identify 'best practices' of academically and professionally qualified teachers, which can then form standards of emulation to enhance teachers' methodological competencies. Specifically, this study is designed to:

- Evaluate the extent to which teachers with academic qualifications and those with professional teaching qualifications use problem-solving methods effectively.

- Assess the extent to which teachers with academic qualifications and those with professional teaching qualifications effectively use individual teaching methods.

- Examine the degree to which teachers with academic qualifications and those with professional teaching qualifications dramatize and demonstrate teaching situations effectively.

\section{Research hypothesis}

It was hypothesized that there are no significant differences in effectiveness between professional and non-professional teachers in their classroom methodological competencies.

\section{Methodological competencies and the art of teaching}

Methodology refers to the processes of teaching and learning which bring the learner into a relationship with the skills and knowledge that are specified and contained within the curriculum (Harris \& Muijs, 2005). In the school, according to Gutek (1988), teaching methods are the means or procedures that teachers use to aid students in having an experience, mastering a skill or process, and/or acquiring an area of knowledge. If efficient and effective, the methods of instruction will achieve the desired end because teaching implies the use of a technique or method of instruction to secure desired objectives. Gutek further observed that educators at all levels of instruction are involved in methodological questions. That is why in programs of teacher education for instance, attention is given to courses on techniques and methods of teaching (mastering learning methods, lecture methods, demonstration methods, dramatizing and discussion methods, questioning methods, problem-solving methods and so on). It is through these methods of teaching that teachers acquire the competencies needed to carry out instructional processes effectively.

Similarly, Colman (1967) described method as an ordered system by which a teacher puts educative agents to work on humans to produce certain changes or result. He acknowledged five essential elements of instructional methodology:

- The specific objective or purpose of instruction

- An introduction that relates the particular lesson to previous learning or experience

- Content or that which is the substance or the subject of a lesson

- A summary to reinforce the particular learning or experience; and

- An evaluation that determines if learners have achieved particular aims (Colman, 1967). 
The Oxford Advanced Dictionary defines methodology as a way of proceeding or doing something, especially if systematic or regular. The same source defines competence as the condition of being capable - having sufficient skill and knowledge. Consequently, methodological competencies could be defined as the procedures of systematically doing something and having enough skill and knowledge to carry out the function at hand. Methodological competencies could be further characterized based on their functional elements: to adapt to effective work methods; to analyze the task to be performed; to begin the process; to perform the task and to analyze one's procedures (Ololube, 2004).

The process of stimulating student excitement and fostering a zest for education that will continue for a lifetime is an elaborate task (Ololube, 2005a). The teaching profession therefore must be fundamentally concerned with the attainment of maximum beneficial learning for each individual. It is the teacher's task to ensure that learning is efficient and effective to allow students to discover their full potentials. In order to carry out the teaching task effectively, teachers are guided by certain principles of teaching and learning, which themselves have great implications for teaching (Gbamanja, 1989). These principles are learned from professional educational institutions established to train potential teachers through their teacher education programs (Ololube, 2005b). Some principles of teaching that reinforce efficient and effective teaching are:

- Planned teaching results in more learning.

- Students tend to achieve in ways they are tested: if students are tested only for facts, they tend only to memorize facts.

- Students learn more effectively if they know the objectives and are shown how to satisfy these objectives. The teacher should spend time discussing the purposes of doing various activities, and experiment with inquiry and the processes used in solving problems.

- The teacher's function in the learning process is one of guidance: guiding individual students to reach objectives.

- Students learn from one another: working in groups while solving problems can enhance learning (Gnamanja, 1989).

One of the most important methods of teaching is mastery learning because it accommodates the natural diversity of ability within any group of students. Beare et al. (1989) observed that using careful preparation and greater flexibility in instructional methods allowed individual students to be appropriately accommodated according to their respective levels of understanding in turn allowing them to progress at their own pace. That is, the role of teacher changes from that of purveyor of all wisdom and becomes that of facilitator of the learning environment. The teacher ensures the availability of resources at the time they are needed and for the duration they are needed. The actual teaching, Beare and colleagues note, will be directed to individuals or to small groups of students dealing with essentially the same problem solving or learning mode, rather than to the entire class. The teacher monitors more closely the progress of individual students and ensures that concepts and processes are understood before the student moves onto the next component. Likewise, Gbamanja (1989) argued that this method of instruction has advantages that could be used to provide remedial materials for individual students, thereby encouraging individual study and freeing teachers from routine teaching. With this approach the participation in the learning task is almost one hundred percent.

The demonstration method of teaching involves the teacher showing students a process or procedure such a science process, a cooking procedure or a computer proce- 
dure. Involving students in demonstrations makes for learning that is less passive and more active (O'Bannon, 2002). It involves showing, doing and telling the students the point of emphasis. It is mostly used as a technique within a method of teaching, and sometimes as a method itself. Gbamanja describes the demonstration method of teaching as a technique within a method used to assist students in discovering the concept of metal where teachers need to demonstrate the physical and chemical properties of several different metals (Gnamanja, 1989). Likewise, in the laboratory, teachers need to demonstrate the use of a microscope to their classes before letting their students use it to discover things themselves and when a science teacher shows the reaction of carbon dioxide on a moist blue litmus paper, he or she is presenting a demonstration. For science subjects, laboratory work is an essential ingredient of the course and some component of this learning is generally preserved, even in students who struggle with other components of the class. In addition to the experience of laboratory work, students often derive a lot of their contact with teachers in the laboratory setting (Forster et al., 1995).

Some people confuse the use of the words demonstration and experiment. While both concepts are related as means of problem-solving and learning experiences in the classroom, they are different (Brown et al., 1959). A laboratory experiment is used as a means of verifying a science while a science demonstration is used as an exhibition lesson or to show parts of an object or show the correct use of equipment (Gbamanja, 1989). It has been suggested that well-trained teachers tend to use the demonstration method effectively in order to aid students' understanding because their competence in teaching stems from the capacity to reach out to different categories of students by creating a rich and multi-dimensional learning environment (Reid et al. 1978). In addition, the competent demonstrator combines the showing, doing and telling of the materials or equipment with (1) examples of ways in which they are used or operated; (2) cautions to be observed in their use; (3) reasons why certain actions are taken and certain results obtained and (4) the importance of each step involved. In this way, students are brought into close personal contact with the materials or equipment demonstrated (Brown et al. 1959).

Dramatizing and discussing are two related types of active learning with wide applicability in modern day schooling. Varied forms of both types have similar basic purposes and values in instructional situations. Indeed, there are occasions when either dramatizing or discussion methods may be chosen as a creative vehicle for achieving specific classroom goals (Brown et al. 1959). However, discussion (specifically) is when two or more people interact verbally with each other. This method could be adopted deliberately in learning situations, though, it sometimes occurs spontaneously as a teacher uses another method of teaching. It can be considered a technique of teaching within a method, and it sometimes occurs at brief intervals during an informal lecture. The discussion method is considered student-centered teaching (Gbamanja, 1989).

The discussion method is seen as naturally inspired or flowing from dramatization (Brown et al. 1959; Gbamanja, 1989). Often, too, both categories of activities are employed in close association. The rewards of these methods of instruction according to the authors are:

- They assist students in developing a sense of confidence through participation and exchange of ideas.

- They encourage participation and involvement in what is going on in the learning environment. In this way students acquire knowledge. 
- They develop positive interpersonal relationships, because the students interact with the teacher and with their colleagues on the basis of their desire to gain knowledge from one another.

- They develop critical and evaluative thinking and listening.

- They give students the opportunity to develop oral communication skills

Courses that can expose teachers to these methodological skills are courses that will enhance a teacher's capacity to handle instructional processes in the classroom. These courses tend to be embedded in the teacher training processes of various faculties of education, or other similar institutions charged with the responsibility of training teachers (Reid et al. 1987). Courses focused on the psychology of education, sociology of education, teaching methods and curriculum development and evaluation play an essential role in teacher education programs that improve teachers' methodological competencies (Gronlund, 2000). Accordingly, Owens noted, "Psychology remains a predominant element in teacher education. Departments of educational psychology in schools of education commonly exert strong influences not only on the content of courses in teaching methods and curriculum but in such topics as test and measurements and statistics that loom so large in the undergraduate and graduate studies of teachers" (Owens, 2004, p. 19). Generally speaking, educational psychology is a method of training and teaching effectiveness. In particular, it is the study of how to help people develop intellectually, especially children who have learning difficulties. Although, research has shown that a teacher's own perception, beliefs, and values guide their interactions with students, the selection of curriculum materials, and organization within the classroom (gleamed from teacher training) does improve their performance (Highet, 1963; Stones, 1966).

\section{Methodology}

\section{Research instrument}

A suitable questionnaire was structured along a four-point likert-type scale (summated) of strongly agree (4), agree (3), disagree (2) and strongly disagree (1) to gather data for the study. This questionnaire was a set of attitude items, all of which are considered of approximately equal "attitude value" and to each of which subjects respond with a degree (intensity) of agreement or disagreement (Kerlinger, 1973). Section "A" of the research questionnaire describes respondents' background information, while section " $\mathrm{B}$ " is comprised of possible methodological competencies. The questionnaire was designed for respondent understanding because different categories of people were chosen as respondents, thus the need to make the questionnaire as straightforward as possible (Denscombe, 2003).

Nworgu's characteristics of a good questionnaire were applied in designing the questionnaire. These characteristics are: relevance, consistency, usability, clarity, quantifiability and legibility (Nworgu, 1991). The questionnaire was also designed with the help of faculty members to elicit information from the respondents that would help gather information on teacher's methodological competencies related to student's educational achievements. It has face validity because the feedback from faculty members helped to determine that the measures reflect the content of the concepts in the questions (Bryman \& Cramer, 1990). 


\section{Analytical framework and procedures}

Simultaneously, to arrive at the intended comparative analyses, several sets of statistical analyses were conducted using SPSS version 13.0: Mean point value, Standard deviation, T-test of significance, ANOVA and Cross Tabulation (N-300). The T-test of significance was computed to test for statistically significant differences in the variables. It is a statistical significance set at $p<0.05$ to assess if the level of confidence observed in the sample also exists in the population. One-way-analysis of variance (ANOVA) was employed to test the relationship between variables and respondents' background information. For a clear and trouble-free comprehension of data, cross tabulation was employed because it is one of the simplest and the most frequently used methods of demonstrating the presence or absence of a relationship (Bryman and Cramer, 1990; 2001; Saunders, et al., 2000).

\section{Population}

The research population for this study was drawn from Rivers State (accessible) of Nigeria (target). It is one of the states in the south-south geo-political zone of the country. The population of the study was comprised of principals, subject heads and teachers from ten (10) randomly selected secondary schools. Supervisors of education from the Ministry of Education and Post Primary Schools Board were also included because they periodically supervised teachers in schools to ascertain their effectiveness. Of the total number of respondents, 270 (90\%) were subject heads and teachers, 10 (3.3\%) were principals, and $20(6.7 \%)$ supervisors. Meanwhile, $76(25.3 \%)$ were academically qualified, while $224(74.7 \%)$ were professionally qualified. While $126(42 \%)$ were female, $174(58 \%)$ were male. 91 (30.3\%) were social science teachers, $136(45.4 \%)$ were science teachers and $73(24.3 \%)$ were humanities teachers. See table 1 for further details.

Table 1. Frequency table for respondents' background information

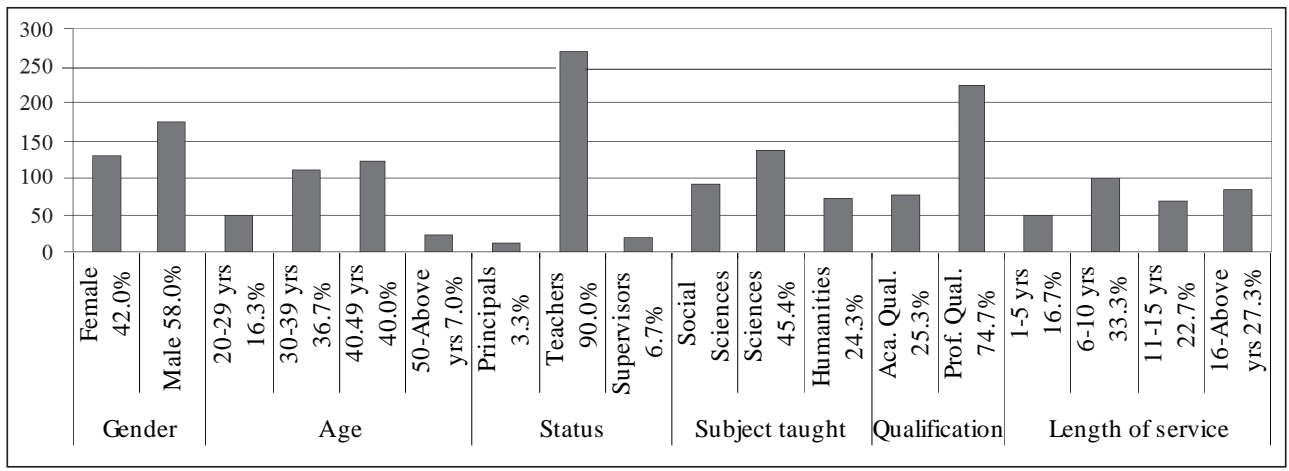

The ANOVA analysis conducted on the respondents' background information showed no significant differences in their attitude towards teacher's methodological competencies $(F=1.71, D f=299, p>0.34)$. Coherence and reliability scales were tested with Cronbach's alpha coefficient. A respectable coefficient of 0.983 was obtained, thus indicating a high inter-item consistency. 


\section{Results}

The first set of statistical analysis for this study began with an analysis of respondent's answers using mean and standard deviation. The goal of these measures is to reveal to what extent teachers' methodological competencies influence students academic achievement. The respondents answers showed that teachers with professional qualifications demonstrate and use problem solving methods more effectively $(M=3.65, S D=0.54)$ than academically qualified teachers $(M=2.07, S D=0.85)$. With respect to dramatizing and demonstrating effectively, the study showed that respondents with professional teaching qualifications better accepted dramatization and demonstration as methods of instruction. This is evident in their mean and standard deviation respectively $(M=3.47$, $S D=0.73 / M=1.84, S D=0.73)$. On the adoption and use of individual teaching methods effectively, it was equally obvious that professionally qualified teachers' mean and standard deviations $(M=3.56, S D=0.56)$ were more than that of teachers with academic qualifications $(M=1.75,0.76,0.75)$, which confirmed that the effective adoption and use individual teaching methods are an essential part of professional teaching (Table 2).

Table 2. Mean and standard deviation of differences between professionally trained and non-professionally trained teachers in the area of methodological competencies

\begin{tabular}{lcccc}
\hline \multirow{2}{*}{$\begin{array}{c}\text { Methodological Competencies } \\
\text { (Variable Items) }\end{array}$} & \multicolumn{2}{c}{$\begin{array}{c}\text { Trained Teachers } \\
\text { (Professionally Qualified) }\end{array}$} & \multicolumn{2}{c}{$\begin{array}{c}\text { Untrained Teachers } \\
\text { (Academically Qualified) }\end{array}$} \\
\cline { 2 - 5 } & Mean & SD & Mean & SD \\
\hline Problem-solving Methods & 3.65 & .54 & 2.07 & .85 \\
\hline Dramatization/Demonst. Methods & 3.56 & .56 & 1.75 & .75 \\
\hline Individual teaching Methods & 3.47 & .73 & 1.84 & .73 \\
\hline Total & 3.56 & 0.61 & 1.89 & 0.78 \\
\hline
\end{tabular}

The second set of statistical analysis was a t-test analysis of paired sample statistics of respondents' perception of teachers' methodological competencies. The purpose of this analysis was to further verify our analytical information; the t-test analysis was aimed at determining if there are significant differences between respondents' means. The results showed that there are significant differences in the methodological competencies between academically qualified teachers and professionally qualified teachers across all the variables. SPSS version 11.5 displayed it as $p<0.000$ significance levels. This does not mean that the probability is 0 . It is less than $p<0.0005$. The highest t-value was 27.08 and the lowest t-value was $-35.69, D f=299, p<0.000$, Therefore, the $\mathrm{H}_{0}$ was rejected (Nworgu, 1991; Marija, 1997; Bryman and Cramer, 2001) (Table 3).

Table 3. Two-tailed test of difference between paired means

\begin{tabular}{lcccccc}
\hline \multicolumn{1}{c}{ Paired Variables } & $\begin{array}{c}\text { Paired } \\
\text { Mean }\end{array}$ & SD. & $\begin{array}{c}\text { Std. Error } \\
\text { mean }\end{array}$ & T & Df & $\begin{array}{c}\text { Significance } \\
\text { (2-tailed) }\end{array}$ \\
\hline Problem-solving Methods & -1.58 & .99 & .057 & -27.48 & 299 & .000 \\
\hline Dram. \& Demon. Methods & -1.81 & .88 & .051 & -35.69 & 299 & .000 \\
\hline Individual Teach. Methods & -1.62 & 1.038 & .060 & -27.08 & 299 & .000 \\
\hline
\end{tabular}


The third set of analysis was the use of Cross Tabulation to demonstrate the presence or absence of a relationship. The data were tallied along agree and disagree responses/ lines. The set of pool questions that compared the two categories of teachers based on the respondents' perceptions showed large differences across all variables. The empirical results revealed that as many as $83.3 \%$ of respondents agree that teachers with professional teaching qualifications use problem-solving methods more effectively (compared to $16.7 \%$ who disagree). With respect to whether academically qualified teachers or professionally qualified teachers better dramatize (demonstrate) teaching situations effectively, results revealed that $72.7 \%$ felt that trained teachers have more propensities to effectively dramatize and demonstrate teaching situations relative to academically qualified teachers. Finally, turning to the adoption and use of individual teaching methods, the information gathered revealed that $75 \%$ agree that trained teachers are more competent in the adoption and effective use of individual teaching methods, relative to $25 \%$ who believe that untrained teachers are more effective in this realm. The overall cross tabulation results suggest that professionally trained teachers are more resultsoriented than their academically trained counterparts (Table 4).

Table 4. Cross tabulation analysis of respondents' answers to the variables

\begin{tabular}{lccc}
\hline N=300 & $\begin{array}{c}\% \\
\text { Problem Solving } \\
\text { Methods }\end{array}$ & $\begin{array}{c}\% \\
\text { Dramatization and } \\
\text { Demonstration Methods }\end{array}$ & $\begin{array}{c}\text { Individual Teaching } \\
\text { Methods }\end{array}$ \\
\hline Untrained Teachers (76) & 16.7 & 27.3 & 25 \\
\hline Trained Teachers (224) & 83.3 & 72.7 & 75 \\
\hline
\end{tabular}

\section{Discussion and conclusion}

Contrary to the expectations and the hypothesis of this research, results showed that there are significant differences in the effectiveness of professional and non-professional teachers when it comes to methodological competencies. The findings at hand suggest that trained teachers take into account the individual differences that exist among students, owing in part to their knowledge of educational psychology. Children who lag behind in their schoolwork are common to all schools and one of the most challenging and chronic problems a teacher will face in their teaching career. These deficiencies are built on a foundation of persistent failure on the part of some children to achieve what other children are achieving, or difficulty in reaching the academic standard set. Professional teachers were much more likely to devote special interest or attention to these students than non-professional teachers.

The findings likewise revealed practical evidence that professional teachers tend to apply more advanced teaching methods (e.g., problem solving methods, dramatisation and demonstration methods) in the teaching and learning processes. This lends support to Janneck and Bleek's (2004) argument that currently teaching practices in the education industry are characterized by a strong emphasis on quality, and special knowledge or professional competencies. These competencies cannot be easily learned individually in lectures or traditional seminars, but require teaching practice and engagement in real teaching contexts. The challenge of conveying these competencies is addressed by offering educational projects to pre-service teachers with a didactic concept that focuses on 
authentic teaching practices. These cooperative projects allow intended teachers to acquire the aforementioned key competencies in an integrative manner.

This study also found that there are relationships between teaching practice and methodological competence. Methodological competence generates input for instructional processes, and instructional processes in turn offer rational input into student's academic achievements. Teaching practices and method courses designed for students at faculties of education equip student teachers with relevant methodological skills that aid teaching and learning. A good example of this is the graduate teacher training registry program in the UK which provides initial teacher training for non-trained would be teachers (GTTR guide for application, 2005).

The analysis also reveals the importance of measurement and evaluation, psychology of education, philosophy of education, sociology of education, educational management, educational planning and other education courses that exposes student teachers to the rudiments of being an effective teacher, because methodological competencies are very much associated with rigor. This gives backing to Law and Clover's (2000) study, where they contended that the rapidly changing environment in educational systems across the globe requires professional competencies in promoting educational development.

Findings in the preceding discussion show that professional teachers play multifaceted roles in effecting quality in teaching. This study's data demonstrated that there are indeed differences in the content and approaches of trained and untrained teachers and that these differences affect their instructional processes. Thus, it could be suggested that a great deal of importance should be attached to developing the skills and methods of untrained teachers because quality teaching scored high in the evaluation of what constitutes an effective teacher. This lends support to the works of Cambell et al. (2004), Creemers (1994b, 1994c), Darling-Hammond (1986, 1987), Darling-Hammond et al. (1995), Leino (1996), and Ololube (2005b).

An effective method of teaching connotes the ability on the part of teachers to communicate, which is reflected in a lucid presentation and the transmission of an enthusiasm that is infectious. Communication here does not merely imply the passing back and forth of sounds, but the art of using the vehicle of sound to sensitize internal reorganizations which aid in the rolling out of new concepts and principles from the learners. This cannot happen if lucid and logical presentations backed by noticeable enthusiasm from teachers are lacking. A good teacher is therefore a person who can communicate with genuine enthusiasm (Amhala, 1979). However, the manner of teaching may be influenced by the teacher's perception, attitude, beliefs and values, which in turn guides his or her interaction with students. Their perceptions, attitudes, beliefs and values can also determines their selection of curriculum materials and organization within the classroom in relation to the four teaching modes (didactic, heuristic, philetic and guristic) as well as their implication for various patterns of curriculum organization and instruction (Gbamanja, 1989). Teacher effectiveness, in contrast to methodological competencies, is the impact that classroom factors, such as the use of classroom teaching methods, teacher expectations, classroom organization, and use of classroom resources, have on students' performance (Cambell et al. 2004).

The broadest implications of this study are such that this study has shown the influences of professional teachers on students to be multi-leveled. This research study has also covered a considerable amount of literature on teacher effectiveness, and various assessments thereof. It discussed a major issue of interest that appeared to be extremely 
important in guaranteeing school effectiveness and quality improvement. It is hoped that this work will be a valuable addition to academic literature on teacher effectiveness, school effectiveness and educational effectiveness in Nigeria and abroad. It is essential in moving forward to have an understanding of the role that teachers' methodological competencies play and this research has helped to explain the meaning and significance of it from a Sub-Saharan African perspective.

The major limitations of this study are that the findings were based on self-reported data on the part of the teachers who served as respondents and are vulnerable to distortions as teachers and their abilities were the focus of the study. Also, researchers are not independent of normative considerations relative to a research problem, therefore, if any part of the analysis in this study bears the hallmarks of being one sided, they should be overlooked and considered as part of our personal learning and growth. Although we have attempted to improve on the generalizability of the results by inferring from a multiple case study, it would be very difficult to arrive at conclusive findings from only ten schools, the Ministry of Education and the Post Primary Schools Board in Rivers State which may not represent the opinions of other teachers in other parts of the country. As this is the case, it remains inappropriate for one to assume that the opinions represented in this study are those of other teachers in Nigeria and beyond. Additional investigation on a wider scale in this direction is in order. A new perspective on teachers' methodological competencies, which does not only take into consideration the unique characteristics of the variables used in this study, is thus recommended. In addition, teacher and school effectiveness researchers should direct their attention to the ways in which both professional and non-professional teachers construct and apply their methodological competencies in schooling students such as grouping procedures and behaviours.

\section{References:}

Amalaha, B. M. (1979). The teacher in the classroom. In B. O. Ukeje (Ed.), Foundations of education (pp. 229-252). Benin-City: Ethiope Publishing.

Austin, H., Dwyer, B., \& Freebody, P. (2003). Schooling the child. London: Routledge Falmer.

Baker, C. D., \& Freebody, P. (1989a). Children's first school books: Introductions to the culture of literacy. Oxford: Basil Blackwell.

Beare, H., Caldwell, B. J., \& Millikan, R. H. (1989). Crating an excellent school: Some new management techniques. London: Routledge.

Bin Mohamed Ali, H. M. (1995). Becoming professionally competent language teachers some suggestions. International Islamic University Malaysia: The English Teacher, 24.

Brown, J. W., Lewis, R. B., \& Harcleroad, F. F. (1959). A-V instruction materials and methods. New York: McGraw-Hill Book Company.

Bryman, A., \& Cramer, D. (2001). Quantitative data analysis for social scientists. London: Routledge.

Bryman, A., \& Cramer, D. (2001). Quantitative data analysis with SPSS Release 10 for Windows: A guide for social scientists. Philadelphia: Routledge: Taylor and Francis Group. 
Campbell, J., Kyriakides, L., Muijs, D., \& Robinson, W. (2004). Assessing teachers job effectiveness: Developing a differentiated model. London and New York: Routledge Falmer.

Colman, J. F. (1967). The master teachers and the art of teaching. New York: Pitman Publishing.

Creemers, B. P. M. (1994a). The history, value and purpose of school effectiveness studies. In Reynolds et al. (Eds.), Advances in school effectiveness research and practice (pp. 9-23). Willington: Elsevier Science.

Creemers, B. P. M. (1994b). Effective instruction: An empirical basis for a theory of educational effectiveness. In Reynolds et al. (Eds.), Advances in school effectiveness research and practice (pp. 189-205). Willington: Elsevier Science.

Creemers, B. P. M. (1994c). The effective classroom. London: Caseell.

Darling-Hammond, I. (1986). Teaching knowledge: How do we test it? American Educator, 10(3), 18-21.

Darling-Hammond, L. (1987). Schools for tomorrow's teachers. Teachers College Record, 88, 356-358.

Darling-Hammond, L., Wise, A. E., \& Klein, S. P. (1995). A license to teach: Building a profession for 21st-century schools. Boulder, CO: Westview Press.

Denscombe, M. (2003). Research guide for small-scale research project. Buckingham: Open University Press.

Dieker, L. A., \& Barnett, C. A. (1996). Effective co-teaching: Teaching exceptional children. Eric Digest, 29(1), 5-7.

Ezewu, E. (1983). Sociology of education. Lagos: Londman Group.

Federal Government of Nigeria (1989). National policy on education: Revised. Lagos: NERDC Press.

Forster, F., Hounsell, D., \& Thompson S. (Eds.). (1995). Tutoring and demonstrating: A handbook. University of Edinburgh: Centre for teaching, learning and assessment.

Gbamanja P. T. (1989). Essentials of curriculum and instruction. Theory and practice. Port Harcourt: Pam Unique Publishing Company.

GTTR (2005). Guide for applicants. Rosehill: Graduate teacher training registry.

Gronlund, N. E. (2000). How to write and use instructional objectives (6th ed.). New Jersey Upper Saddle River.

Gutek, G. L. (1988). Philosophical and ideological perspectives on education. Englewood Cliffs, N.J. Prentice Hall.

Harris, A., \& Muijs, D. (2005). Improving schools through teacher leadership. Berkshire: Open University Press.

Highet, G. (1963). The art of teaching. London: Methuen.

Janneck, M., \& Bleek, W. (2004). Project-based learning with comsys. Retrieved October 14, 2004, from http://newmedia.colorado.edu/cscl/104.html

Kerlinger, F. N. (1973). Foundation of behavioral research. New York: N. Y. Holt Rienehart and Winston.

Law, S., \& Clover, D. (2000). Educational leadership and learning: Practice, policy and research. Buckingham: Open University Press.

Leino, J. (1996). Developing and evaluation of professional competence. In P. Ruohotie \& P. P. Grimmett (Eds.), Professional growth and development: Direction, delivery and dilemmas. Canada and Finland: Career Education Books.

Marija, J. N. (1997). SPSS 6.1 guide to data analysis. New Jersey: Prentice Hall. 
Marshall, H. H. (1987). Motivational strategies of three fifth-grade teachers. The Elementary School Journal 88, 2, 135-50.

Nworgu, B. G. (1991). Educational research: Basic issues and methodology. Ibadan: Wisdom Publishers.

O'Bannon, B. (2002). What are instructional methods? Retrieved December 10, 2005, from http://edtech.tennessee.edu/ bobannon/instructional methods.html\# demonstration

OECD (1989). Schools and quality: An international report. Paris: OECD.

Ololube, N. P. (1997). An appraisal of teachers' perception of academic and professional training on teachers' job effectiveness in secondary schools in Ndokwa East Local Government Area of Delta state of Nigeria. Unpublished Masters' degree thesis, Delta State University, Abraka, Nigeria.

Ololube, N. P. (2005a). Benchmarking the motivational competencies of academically qualified teachers and professionally qualified teachers in Nigerian secondary schools. The African Symposium, 5(3), 17-37.

Ololube, N. P. (2005b). School effectiveness and quality improvement: Quality teaching in Nigerian secondary schools. The African Symposium, 5(4), 17-31.

Ololube, N. P. (2004). Professionalism: An institutional approach to teachers' job effectiveness in Nigerian schools. A paper presented at the 7 th international LLinE conference, September 23-25, 2004.

Owens, R. G. (2004). Organizational behavior in education: Adaptive leadership and school reform (8th ed.). Boston: Pearson Education.

Reid, K., Hopkins, D., \& Holly, P. (1987). Towards the effective school. Oxford: Basil Blackwell.

Saunders, M., Lewis, P., \& Thornhill, A. (2000). Research methods for business studies (2nd ed.). Harlow: Printice Hall.

Stones, E. (1966). An introdction to educational psychology. London: Methuen.

Suzanne, R. (1997). Collaboration between general and special education. Eric Digest.

The New Curriculum (2003). Teaching insight and modes of teaching. Retrieved June 17, 2009, from http://www.newcurriculum.com/2003/ed9-17.htm

\section{Correspondence:}

Dr Nwachukwu Prince Ololube, Department of Educational Foundations and Management University of Education, Port Harcourt, Nigeria. E-mails: ololubenp@gmail.com or ololubeprince@yahoo.com 